\title{
Treatment of Shallow Groundwater Quality for Non-potable Use: A Case Study in Parit Raja, Batu Pahat, Johor
}

\author{
Fitryaliah Mohd Shahli ${ }^{1}$, Siti Nazahiyah Rahmat ${ }^{1}{ }^{*}$, Siti Nor Aishah Mohd Salleh ${ }^{1}$ and Syafiqa Ayob ${ }^{1}$ \\ ${ }^{1}$ Faculty of Civil and Environmental Engineering, \\ Universiti Tun Hussein Onn Malaysia, \\ 86400 Batu Pahat, Johor, Malaysia \\ *Corresponding author E-mail: nazahiya@uthm.edu.my
}

\begin{abstract}
Groundwater becomes an alternative water resource to meet up the demand of clean water in our country. Unfortunately, several contaminants could present in groundwater make it unsafe for domestic used and drinking water purpose. Therefore, groundwater should be treated to acceptable level before it can be consumed for further use. The aim of this study was to improve the groundwater quality in terms of physical parameters and bring it within the acceptable level using simple and economical aeration and filtration methods. Gravel, ceramic and charcoal were used as filter materials. The removal efficiency was determined from the calculated percentage removal of the tested parameters. Based on the results, groundwater showed improvement in its physical quality with percentage removal of turbidity, BOD and COD at 92\%, 73\% and 79\%, respectively. Parameter $\mathrm{pH}$ also showed good improvement from slightly acidic to neutral range. However, TDS gave different results. With the exception of TDS, all parameters comply with the Malaysia's standard of raw and drinking water quality set by Ministry of Health.
\end{abstract}

Keywords: Aeration; filtration; groundwater quality; physical parameters.

\section{Introduction}

Malaysia has the abundance of water resource and receives an average $3000 \mathrm{~mm}$ rainfall per annual year [1].However, despite the high volume of surface water available to meet the demand, water shortages issues have occurred in Malaysia. Population growth, municipal development, industrialization, and irrigation of agriculture as well as climate change have strengthen the growing demand and pressure on Malaysia's water resources, thereby enhancing water pollution [1]. In addition to pollution issues, the water supply especially from dams will not be sufficient for daily use when especially in dry period. Therefore, groundwater is one of the potential water sources that can be used in the possibility events of drought or no water supply [2]

Groundwater has been obtained by digging wells and natural springs [3]. In Malaysia, especially in Kelantan, there are nearly $70 \%$ of the populations using groundwater for public and domestic supplies [2]. In certain parts of rural areas in our country, the dependent on groundwater from wells and shallow tube wells is still high to meet the daily needs [3].

Groundwater and source of groundwater can be affected by type of soil, human activity, climate relief, and time [4]. Groundwater quality problems are typically associates with the high hardness, high salinity, and elevation of others heavy metal that can harm to human health [5]. The contaminated groundwater cannot be used for drinking purpose as high concentration of anions (such as chloride and sulphate) [6] and heavy metals (such as lead and copper) can lead to a serious health threats to human beings [7]. Thus, this contaminated groundwater need to be treated properly before further use.

There are many treatments that can be used to improve the quality of the groundwater namely, aeration, filtration, and chlorination. Multiple water treatment methods may be necessary in some cases as single treatment method is insufficient to improve the groundwater quality for a specific requirement (e.g. bathing, ablution, etc) [8]. However, the simplest treatment method should be selected if low-quality extracted water is adequate for any applications [9].

One of the common methods is aeration. According to Daud et. al., [10], aeration process consists of two methods which are water-into-air and air-into-water. The water-into-air method is conducted by letting air passing through water to reduce carbon dioxide while for air-into-water method; air is diffused into water and usually through the hollow pipes, porous plates, or tubes. Meanwhile, filtration process is the process of filtering impurities and foreign substances in water [11]. It involves few technical components and usually do not contain chemicals. The quality of the treated water and maintenance requirements for the system depends on the media used [12][10].

There are few types of media that can be used as the filter media. Among them are gravel, sand, ceramic, and activated carbon. The gravel sand usually uses as a filter media to remove debris and dirt in the water before it go through next treatment. It is also significant in removing colors, turbidity (suspended particles such as silk and clay), and microorganisms [13]. Ceramic media is a manmade material, cheap, and effective type of water filter, which can be used to treat water effectively by removing dirt, debris, and bacteria out of groundwater by relying on the small pore size of 
ceramic materials. According to Musa at. al., [12] ceramic will not alter the $\mathrm{pH}$ balance but will increase the surface area available for bacteria colonisation by enhancing biological filtration. Ceramic media filtration uses porous ceramic (fired clay) to filter microbes or other contaminants from the groundwater. Activated carbon commonly made from charcoal. Activated carbon effectively removes chlorine, organic chemicals, unpleasant odor, and color [14]. Activated carbon can be produced in a variety of different physical forms. Large surface area gives good absorption ability and is commonly used in the raw water intake and gravity filters.

Therefore, the main aim of this study is to improve the groundwater quality by simple yet effective treatment methods which are aeration and filtration. This experimental study is set up by primarily investigating the groundwater quality, installing the treatment system, and calculating the efficiency of the method by calculating the percentage of removal.

\section{Methodology}

\subsection{Study Area}

The study area was located at Hydro-Meteorology Station, University Tun Hussein Onn Malaysia (UTHM) (Fig. 1). Generally, the location has flat topography and surrounded with private factory, university buildings (laboratory, class and offices), and golf course. Based on the site observation, thick wet clay and silt geomaterial can be easily found. The area was found with high water content derived from high water table of lowland areas. There were three existing tube wells in which two of them were the observation wells and the other one was used to extract groundwater. The tube well was $30 \mathrm{~m}$ depth and $100 \mathrm{~mm}$ in diameter. Groundwater was pumped out from the borehole using purging pumps to running the groundwater treatment system.

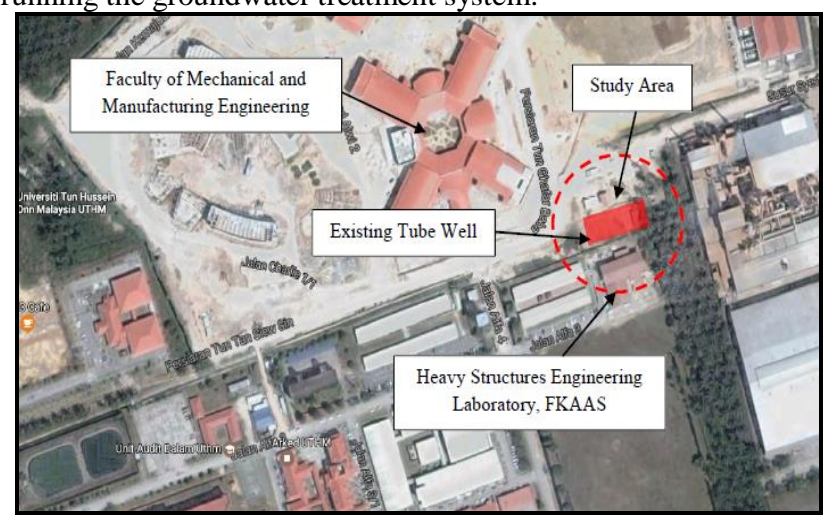

Fig. 1: Location of the study area

\subsection{Groundwater Treatment System Method}

Fig. 2 shows the complete treatment which consists of aeration process (fountain), sedimentation, and filtration. Groundwater from the existing tube well was pumped and channelled to the fountain (aeration process) (Fig. 3) to help in reducing the amount of carbon dioxide (decarbonation) which usually found in groundwater. Then it was stored in the sedimentation tank for 24 or 48 hours. During this time period, the sediment would settle at the bottom of the water tank. The water was then passing through the filtration tank and flowing into the storage tank.

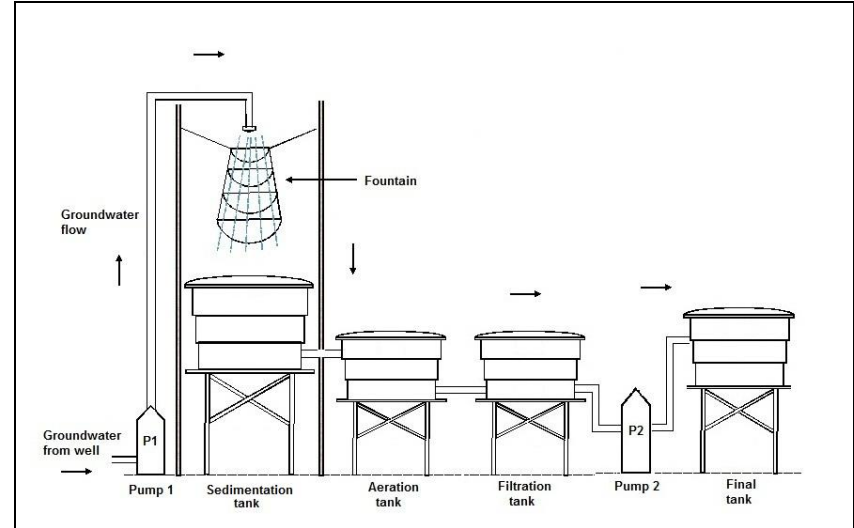

Fig. 2: Sketch up of complete treatment system

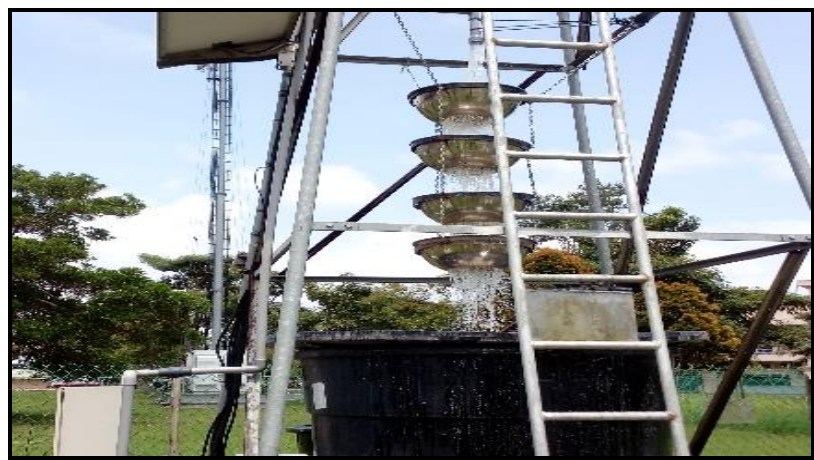

Fig. 3: Water-into-air aeration method (fountain)

The filtration system consisted of several materials which were gravel sand, ceramic media, and activated carbon. Fig. 4 shows the layer of filtration tank. The bottom layer of the filtration tank was filled up with the gravel sand $(6-15 \mathrm{~mm})$ for $10 \mathrm{~cm}$ height and followed by medium gravel or course sand $(1-6 \mathrm{~mm})$ for $10 \mathrm{~cm}$ above the gravel sand. Ceramic was crushed into medium pieces $(1-10 \mathrm{~mm})$ size and filled into the filtration tank for $15 \mathrm{~cm}$ height above the gravel sand media. For the upper part of filter media, conventional activated carbon (charcoal) was used. The activated carbon was filled in the filtration tank for $5 \mathrm{~cm}$ height above the ceramic media. Then, filtered water was passing through 5 micron polypropylene fibre filter before it was stored in the final tank.

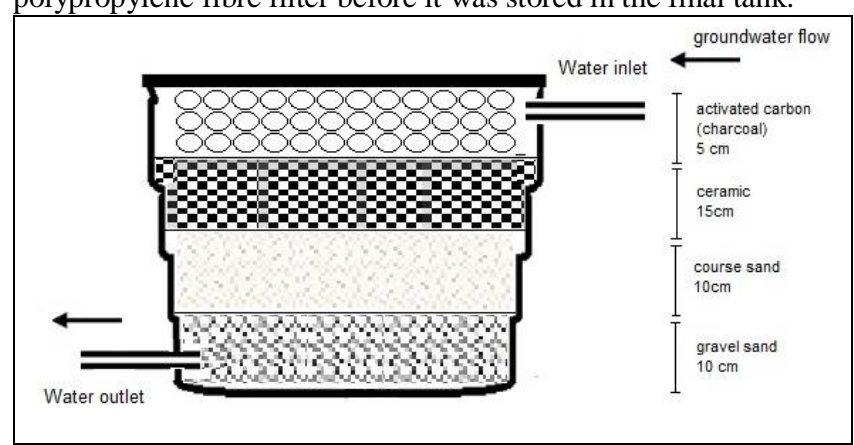

Fig. 4: filtration tank

\subsection{Sampling and Analysis}

In this study, six (6) samples before and after treatment were collected on 11 April, 18 April and 25 April 2017. Two bottles of groundwater samples were collected from tube well using a bailer for control samples and another two bottles of treated groundwater samples were directly collected from final tank. All sampling bottles were washed with dilute acid (sulphuric or hydrochloric) and thoroughly rinsed with deionised-distilled water. The collected samples were immediately brought to the laboratory to test the water quality. The water samples were stored in a box of control temperature which was about $4^{\circ} \mathrm{C}$ to $10^{\circ} \mathrm{C}$. This to ensure the wa- 
ter samples would not be affected by the surrounding and thus, minimized the errors. The in-situ parameters ( $\mathrm{pH}$ and TDS) were tested by using HANNA HI9829 Portable Multi-parameter meter.

Few parameters were tested namely, Biochemical Oxygen Demand (BOD), Chemical Oxygen Demand (COD), pH, turbidity and total dissolved solid (TDS). All testing procedures followed the Standard Method for the Examination of Water and Wastewater [15]. The percentage removal of each parameter was calculated to obtain the efficiency of aeration and filtration techniques in improving groundwater quality.

\section{Result and Discussion}

Fig. 5 shows groundwater samples before and after the full treatments. From the observation, it could be observed that, the groundwater was apparently clear after the full treatment processes.

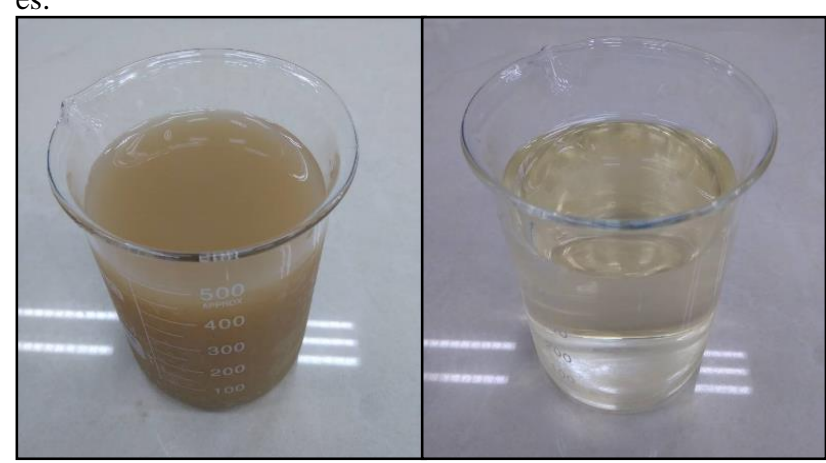

Fig. 5: Groundwater samples before (left) and after full treatment (right)

Table 1 shows the average values of groundwater samples before and after the full treatments. From the result, it showed that all parameters portrayed good improvements with high percentage of removal. Parameter $\mathrm{pH}$ of groundwater samples improved from slightly acidic to neutral range. The average percentage removal of turbidity, BOD and COD showed percentages of removal with $92 \%, 72.7 \%$ and $89.3 \%$ respectively. It was complying with Recommended Raw Water Quality by Ministry of Health, Malaysia and could be used safely for non-potable purpose such as flushing toilet, laundry, washing car, and watering plant.

Table 1: Average values before and after the treatment

\begin{tabular}{|l|l|l|l|l|l|}
\hline Parameter & $\mathrm{pH}$ & $\begin{array}{l}\text { Turbidity } \\
(\mathrm{NTU})\end{array}$ & $\begin{array}{l}\mathrm{BOD} \\
(\mathrm{mg} / \mathrm{l})\end{array}$ & $\begin{array}{l}\mathrm{COD} \\
(\mathrm{mg} / \mathrm{l})\end{array}$ & $\begin{array}{l}\text { TDS } \\
(\mathrm{mg} / \mathrm{l})\end{array}$ \\
\hline $\begin{array}{l}\text { Before } \\
\text { treatment }\end{array}$ & 6.4 & 78.0 & 0.7 & 469.7 & 1924 \\
\hline $\begin{array}{l}\text { After } \\
\text { treatment }\end{array}$ & 7.2 & 6.3 & 0.2 & 50.3 & 1262 \\
\hline $\begin{array}{l}\text { Recommended } \\
\text { Raw } \\
\text { Water }\end{array}$ & $5.5-9.0$ & 1000.0 & 6.0 & 10.0 & 1500 \\
\hline $\begin{array}{l}\text { Percentage of } \\
\text { removal (\%) }\end{array}$ & - & 92.0 & 73.0 & 89.3 & 34.4 \\
\hline
\end{tabular}

For TDS values, only $34.3 \%$ of TDS values could be removed. The high concentration value of TDS before the treatment was contributed by the accumulation of ions in the respective water [16]. Thus, high values of TDS indicated the groundwater had been influenced from seawater intrusion [17]. According to previous studies by Musa et. el., [18] the groundwater in the study area was affected by seawater intrusions due to the near location with sea borders about $20 \mathrm{~km}$. This area was also found with sediment and sedimentary fossils formed due to tidal effects in the old centuries. Hence, value of TDS was high.

\section{Conclusion and Recommendation}

Groundwater is one of the water sources that is very important in our country as it can be used as alternative water sources in Malaysia. Groundwater contamination can cause health diseases if it is consumed without being treated. Based on the results obtained, aeration and filtration methods were effective in improving groundwater quality. However, further analysis should be made to find more appropriate medium as filter material. All parameters showed improvement in water quality. The average percentage removal of turbidity for three samples was $92 \%$. For $\mathrm{pH}$ value, the water quality was improved from acidic to neutral and met the standard requirement. While for BOD, COD and TDS, the average percentages removal were $73 \%, 89 \%$ and 34.4 respectively. All the parameters complied the Recommended Raw Water Quality by Ministry of Health, Malaysia.

The study's objectives to study the groundwater quality and to check the efficiency of the proposed filter were achieved. The proposed filter was efficient in removing and improving water quality for BOD, COD, $\mathrm{pH}$ and turbidity. The filter medium such as gravel, charcoal, and ceramic media were efficient in improving water quality. In conclusion, these aeration and filtration techniques were suitable to be used in improving groundwater quality. Further studies such as analysis on the cation, anion, and other elements such as heavy metals need to be carried out to identify the possible parameters that give high concentration, which can cause high TDS in the samples.

A few recommendations have been identified for further researches such as different filter mediums need to be tested to get the best results in improving groundwater quality at this area. Moreover, maintenance on the filter needs to be done regularly to make sure it is clean and does not give any effect to the water quality. More water samples need to be analysed in order to get reliable results. It is hoped that the groundwater quality can be improved in the future and can be used as an alternate water source in the country.

\section{Acknowledgement}

Authors would like to thank Fundamental Research Grant Scheme (FRGS) (Vote 1523) and Grant Penyelidikan Pasca Siswazah (GPPS) (Vote U780), for the supports that allow us to carry out this research.

\section{References}

[1] Suratman, S., 2004. IWRM: Managing the groundwater component in Malaysia. Malaysia Water Partnership (MyWP) 2004, Kuala Lumpur. 1-11.

[2] Akbar, N. A., Aziz, H. A., Adlan, M. N., (2015). Potential Used of Ozonation with Limestone Adsorption in Groundwater Treatment: A Case Study at Kelantan Water Treatment Plant. Jurnal Teknologi UTM, 2180-3722

[3] Abd Razak, Y., Abd Karim, M. H., (2009). Groundwater in Malaysia Context. Proceeding of the Groundwater Colloquium 2009. Putrajaya.

[4] Fitts, C. R. (2002). Groundwater Science (Vol. 2). London: Academic Press.

[5] Abdul Aziz, N.I., Othman, N. (2016). Groundwater Quality and soil characterization: A case study of Bukit Tembaga, Kuala Nerang, Kedah. MATEC Web of Conferences 103, 05011

[6] Aris, A. Z., Abdullah, M.H., \& Kim K. W. (2007). Hydrogeochemistry of Groundwater in Manukan Island, Sabah. The Malaysian Journal of Analytical Sciences, 407-413.

[7] Zakariah, U. K. (2017). Hydrochemical Analysis and Evaluation of Groundwater Quality in UTHM. Degree Thesis. University Tun Hussein Onn.

[8] Abd Wahid, S. (2014). Rawatan Fizikal Air Hujan Menggunakan Penapis Pasir Kelikir, Penapis Zeolit dan Penapis Arang. Degree Thesis: Universiti Tun Hussien Onn Malaysia 
[9] Musa, S., Denan, F., Hamdan, R., and Radin Mohamed, R. M. S. (2015). Natural Groundwater Eco-Treatment (N-GET) for Water Supply at Johor, Malaysia. Journal of Advanced Research in Fluid Mechanics and Thermal Sciences. ISSN (online): 2289-7879

[10] Daud, N., Izehar. N., Yusuf, B., and Mohamed, T., (2013) "Groundwater quality improvement by using aeration and filtration methods," World Acad. Sci.

[11] Muhammad, N., Ellis, K., Parr, J., Smith, M. D., (1996). Optimization of slow sand filtration. 22nd WEDC Conference, Reaching the Unreached: Challenges for 21st Century, New Delhi, India

[12] Musa, S., Ariff, N., Abdul Kadir, M., \& Denan, F. (2015). Simplified Method for Groundwater Treatment Using Dilution and Ceramic Filter, Soft Soil Engineering International Conference 2015 (SEIC2015)

[13] Rahmat, S. N., Ali,Z. M., and Musa, S. (2008)."Treatment of Rainwater Quality Using Sand Filter," Int. Conf. Environ. 2008 (ICENV 2008), vol. 2008, no. Icenv, pp. 1-8,

[14] Kadir, M. N. A. (2016). Removal of Chloride and Sulphate from Groundwater using Natural Groundwater Eco-Treatment System. Master Thesis. University Tun Hussein Onn.

[15] Eaton, L.S. (1999). Standard Methods for the Examination of Water and Wastewater, (20nd Edition). American Public Health Association

[16] M. Radojevic and V. N. Bashkin (2006), Practical Environmenta Analysia. RSC Publishing.

[17] N. Umar Kura, M. Firuz Ramli, W. N. Azmin Sulaiman, S. Ibrahim, A. Zaharin Aris, and A. Mustapha, (2013), "Evaluation of factors influencing the groundwater chemistry in a small tropical Island of Malaysia," Int. J. Environ. Res. Public Health, vol. 10, no. 5, pp. 1861-1881.

[18] Musa, S., Zakaria, N., Radin Mohamed, R., Amir, M. and Ibrahim, M. (2013). Kaedah Lestari Bio-serapan Dalam Merawat Air Bumi Menggunakan Bahan Organik. Prosiding Seminar Kebangsaan Aplikasi Sains dan Matematk 2013 (SKASM2013) 